\title{
Marine cyanobacteria in tropical regions: diversity and ecology
}

\section{LUCIEN HOFFMANN}

University of Liège, Institute of Botany (B.22), Sart Tilman, B-4000 Liège, Belgium

(Received 15 January 1999; accepted 17 June 1999)

Tropical marine ecosystems are characterized by a specific cyanobacterial flora, temperature most probably being the major factor limiting the geographic distribution of the species. When compared with the open ocean, the highest biodiversity of cyanobacteria is observed in the littoral zones where they form intertidal and infralittoral mats, live as endoliths in carbonate substrates or form symbiotic associations, especially with sponges and ascidians. Their diversity, which especially in the less accessible infralittoral is still largely unknown, is also a source of diverse bioactive compounds, some of which are important as herbivore deterrents. As photosynthetic organisms, cyanobacteria sensu lato (including Prochlorophyta) are important contributors to benthic and open ocean primary production, but their main role in the tropical marine ecosystems appears to be as nitrogen fixers. Of primary importance in the often oligotrophic tropical oceans is the nonheterocystous, planktonic bloom-forming Trichodesmium, which probably represents a major nitrogen source for the marine and global nitrogen cycle.

Key words: biodiversity, biogeography, Cyanobacteria, Cyanophyta, marine, nitrogen fixation, secondary metabolites, tropics

\section{Introduction}

The existence of Precambrian fossil stromatolites containing evidence of oxygenic photosynthesis and fossil endoliths similar to living species (Golubic \& Knoll, 1993) indicates the long evolutionary and biochemical history of marine cyanobacteria. Contemporary marine cyanobacteria still play important roles, especially in tropical ecosystems (the phytogeographical subdivisions of the oceans as defined by Van den Hoek (1984) for macroalgae are applied here: the tropical oceanic area is thus limited by the $20{ }^{\circ} \mathrm{C}$ winter isotherm of the seawater, whereas in the temperate regions water temperature drops to $10{ }^{\circ} \mathrm{C}$ ), where they have a high biodiversity, are widespread, and may sometimes occur in striking abundance. It was probably a red-pigmented bloom-forming species of the genus Trichodesmium which gave the Red Sea its name (Fogg, 1982). The assessment of the biodiversity of cyanobacteria depends on a reliable taxonomy in order definitively to recognize genetically different entities in nature. Modern molecular phylogenetic studies are currently restricted to axenic cultures and DNA mixtures extracted from natural populations. Ecological research will, therefore, continue to depend on the phenotypic identification of cyanobacteria. On the other hand, taxonomic studies of cyanobacteria have neglected marine environments, especially in tropical regions. Identification manuals include only a small fraction of genuine marine cyanobacterial taxa. Consequently, floristic surveys have frequently applied names of freshwater taxa when reporting cyanobacteria from marine habitats.

Renewed interest in marine cyanobacteria was generated in conjunction with the study of marine picoplankton and its contribution to oceanic primary production (Waterbury et al., 1979; Johnson \& Sieburth, 1979), while planktonic filamentous cyanobacteria attracted attention as important contributors to the nitrogen cycle in the ocean as well as toxin producers (see e.g. Sellner, 1997). In contrast, interest in marine benthic cyanobacteria has mostly been limited to intertidal environments, which were used as model systems for the interpretation of fossil stromatolites.

Oxygenic photosynthetic prokaryotes have been placed in two divisions: cyanobacteria (Cyanophyta) characterized by the presence of chlorophyll $a$ and phycobiliproteins, and the Prochlorophyta, also called Oxychlorobacteria, characterized by the possession of chlorophylls $a$ and $b$, and the absence of phycobilisomes. Sequence analyses have shown, however, that the prochlorophytes are a polyphyletic group residing within the cyanobacterial lineage (Turner, 1997). In the following review, the term 'cyanobacteria' is used in a wide sense, including all oxygenic, photosynthetic prokaryotes (= oxyphotobacteria sensu Murray, 1989). The nomenclatural system followed is that of Geitler (1930-2).

Cyanobacteria occupy a wide range of niches in marine ecosystems in tropical regions where they occur along maritime coasts as well as in the open ocean. The environmental constraints to which they are exposed vary widely in these two habitat categories, so that their biodiversity and ecology in the benthic and planktonic environments will be considered separately.

\section{Littoral cyanobacteria}

\section{Cyanobacteria of intertidal and supratidal zones}

Benthic cyanobacteria are widespread along maritime coasts, often forming visually conspicuous growths on rocks and sediments as mats and epilithic growths. A 


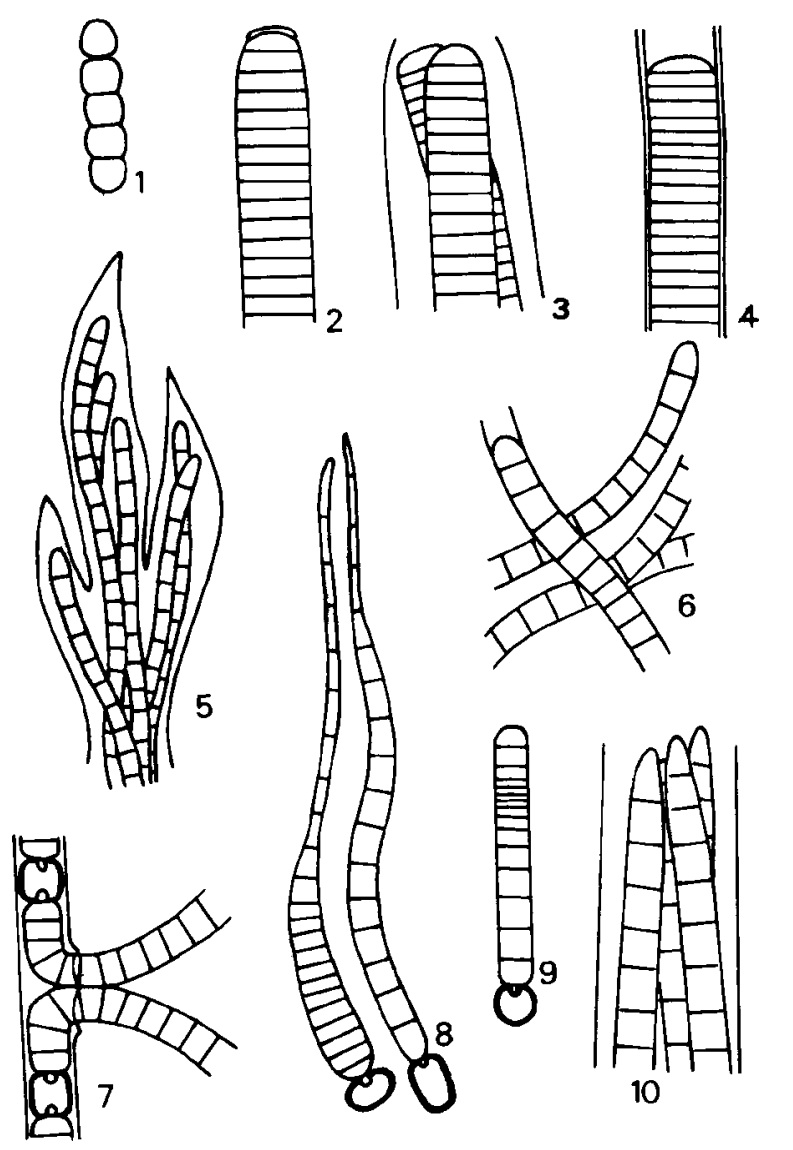

Figs 1-10. Representative cyanobacterial genera of the tropical marine benthos. Fig. 1. Borzia Gomont. Fig. 2. Oscillatoria Gomont. Fig. 3. Hydrocoleum Gomont. Fig. 4. Lyngbya Gomont. Fig. 5. Schizothrix Gomont. Fig. 6. Phormidium Gomont. Fig. 7. Scytonema Bornet et Flahaut. Fig. 8. Calothrix Bornet et Flahaut.

Fig. 9. Microchuete Bornet et Flahaut. Fig. 10. Microcoleus Gomont.

littoral fringe containing lichens and cyanobacteria is of almost universal occurrence on rocky shores (Stephenson \& Stephenson, 1949) and has also been described from tropical regions such as around the Seychelles (Taylor, 1968).

The occurrence of extensive mats of cyanobacteria is observed on or in much tropical coastal sand and silt. Many of the more complex types play an important role in building and trapping sediments and/or in carbonate precipitation (Golubic, 1973). Some of these littoral communities dominated by cyanobacteria are restricted to warm waters; this is especially true for those which form well-developed stromatolites, which are lithified mats. Many examples of stromatolites have been described (Walter, 1976). They are most abundant in lagoons and sheltered coastal localities; some of the best-developed examples, such as those at Shark Bay (Western Australia) or in the Persian Gulf, are found in hypersaline waters.

On moving from the supralittoral down to the intertidal zone, mats often show a zonation. The distribution of the types of mats is determined by the frequency and duration of subaerial exposure, wave energy, and the type and amount of sediment transported by tidal currents (e.g. Golubic, 1985). The surface morphology of mats depends on the prevailing environmental conditions, but also on

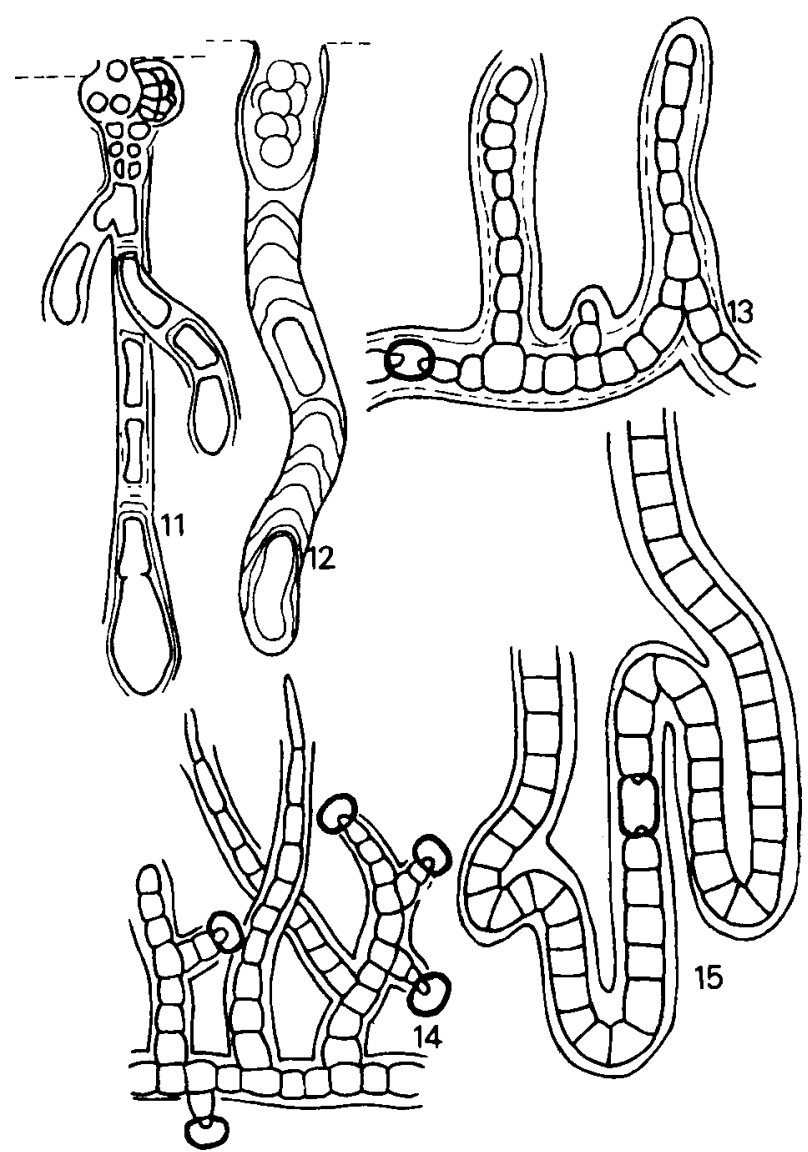

Figs 11-15. Representative genera of tropical marine endolithic cyanobacteria, Fig. 11. Hyella Bornet et Flahaut. Fig. 12. Solentia Ercegovic. Fig. 13. Herpyzonema Weber-van Bosse. Fig. 14. Mastigocoleus Bornet et Flahaut. Fig. 15. Kurtuthrix Ercegovic.

the dominant species (Golubic \& Focke, 1978; Zhang \& Hoffmann, 1982).

The intertidal zone is often dominated by sheathproducing taxa of filamentous non-heterocystous (Lyngbya, Microcoleus, Phormidium, Schizothrix) and heterocystous (Rivularia Bornet et Flahaut, Calothrix, Scytonema) genera (Figs I-10). Vertical sections of mats usually include various groups of prokaryotes in discrete coloured layers. The surface layer is often dominated by the cosmopolitan Lyngbya aestuarii Gomont. This species seems to be protected from excessive radiation by the brown extracellular sheath pigment 'scytonemin' (GarciaPichel \& Castenholz, 1991). Another common and geographically widespread member of microbial mats is Microcoleus chthonoplastes Gomont.

Mangrove forests, common along many tropical and some subtropical coastal lagoons are inhabited by diverse cyanobacterial communities which reside on leaf and root litter, live roots, and often form extensive mats on the surrounding sediments (e.g. Potts, 1979, 1980; Potts \& Whitton, 1980; Sheridan, 1991; Hussain \& Khoja, 1993; Toledo et al., 1995; Phillips et al.. 1996); many of these communities are capable of $\mathrm{N}_{2}$ fixation. The genera Oscillatoria, Lyngbya, Phormidium and Microcoleus are widespread in these habitats, as are heterocystous genera, such as Scytonemar in some areas (Potts, 1979). Vertical 
Table 1. Floristic survey of marine cyanobacteria in Papua New Guinea (Hoffmann, 1989, 1993; Hoffmann \& Demoulin, 1991, 1993).

\begin{tabular}{lccc}
\hline \hline & No. of & No. of species & No. of \\
genera & and subspecies & new taxa \\
\hline CHROOCOCCALES & 14 & 20 & 5 \\
Chamaesiphonaceae & 2 & 4 & 2 \\
Chroococcaceae & 1 & 1 & - \\
Dermocarpellaceae & 1 & 1 & - \\
Hydrococcaceae & 4 & 7 & 3 \\
Microcystaceae & 4 & 5 & - \\
Prochloraceae & 1 & 1 & - \\
Xenococcaceae & $\mathrm{I}$ & 1 & 17 \\
OSCILLATORIALES & 9 & 41 & 17 \\
Oscillatoriaceae & 9 & 41 & 3 \\
NOSTOCALES & 5 & 13 & 1 \\
Microchaetaceae & 1 & 2 & - \\
Nostocaceae & 1 & 2 & - \\
Rivulariaceae & 2 & 7 & - \\
Scytonemataceae & 1 & 2 & - \\
STIGONEMATALES & 3 & 3 & - \\
Mastigocladaceae & 2 & & - \\
Nostochopsidaceae & 1 & & \\
\hline \hline
\end{tabular}

zonation is often observed on the pneumatophores or prop roots.

Cyanobacteria that live inside limestone rocks are also an important feature of intertidal habitats (Radtke et al., 1997). The colonization of marine rocks by endoliths can be very rapid (Perkins \& Tsentas, 1976; Potts \& Whitton, 1980). The cyanobacterial endolithic assemblages exhibit a well-defined zonation pattern which is recognized by changes in the dominance and abundance of the different species and can be correlated with differences in tidal range and the vertical distribution of the macroflora and macrofauna (Hoffman, 1985; Radtke et al., 1996; Taton \& Hoffmann, 1999). The upper ranges are generally dominated by Herpyzonema, Hormathonema Ercegovic, Scytonema, Solentia and Kyrtuthrix, whereas Mastigocoleus (Figs 11-15) generally appears only in the lower intertidal zone. The major difference between temperate and tropical carbonate coasts seems to lie in the presence and often dominance of Herpyzonema intermedium Weber-van Bosse in tropical regions (Hoffman, 1985; Taton \& Hoffmann, 1999), whereas in temperate regions such as the Mediterranean Sea (Le Campion-Alsumard, 1979), Hyella balani Lehmann seems to occupy the niche of the latter species in the intertidal zone.

\section{Cyanobacteria of the infralittoral zone}

Conspicuous growths of sublittoral benthic mats are frequently recorded from warmer waters, where films of filamentous species overlying sand in shallow water appear to be relatively common. In contrast to those found in the intertidal, they are simpler, generally do not show a vertical zonation, and consist of films of interwoven filaments, often of single species. Thick mats can extend to the lower part of the shore in sheltered, moderately hypersaline conditions (Potts \& Whitton, 1980; Bauld et al., 1992) and can even form stromatolites (Golubic \& Browne, 1996). Mats with cyanobacteria have been observed to depths of $50 \mathrm{~m}$, but in general growth appears to be most rapid in depths of less than $10 \mathrm{~m}$. These superficial mats become established where rates of sediment movement and turnover by grazers and especially by burrowers are low (Whitton \& Potts, 1982).

In the infralittoral zone a very high biodiversity is found, especially near coral reefs, where the oscillatoriacean genera (Oscillatoria, Hydrocoleum, Microcoleus) are represented by many taxa, some of which remain to be described (e.g. Hoffmann \& Demoulin, 1993; see also Table 1). Little information is available about their ecology, including their interactions with herbivores, although some reports mention that they are heavily grazed, for instance by holothurians (Sournia, 1976).

Epiphytic cyanobacteria (especially Calothrix, Microchaete, Lyngbya) are present on pelagic macroalgae such as Sargassum C. Agardh (Phlips et al., 1986), and on benthic macroalgae and seagrasses (e.g. Brouns \& Heijs, 1986; Klumpp et al., 1992; Hoffmann, 1993), together with diatoms, Chlorophyta and Rhodophyta. These epiphytic communities are important contributors to the overall productivity (Moncreiff et al., 1992) and are a major food source for macroinvertebrate grazers (Klumpp et al., 1992; Mukai \& Iijima, 1995). Many of these epiphytic cyanobacteria are heterocystous and thus fix $\mathrm{N}_{2}$, which may contribute to the marine nitrogen budget (e.g. the estimated nitrogen input by epiphytic cyanobacteria on Sargassum amounts to $0.01810^{9} \mathrm{~g} \mathrm{~N}_{\text {year }}{ }^{-1}$, Capone \& Carpenter, 1982).

The tropical regions are also characterized by particularly diverse endolithic cyanobacterial communities (including e.g. the genera Hyella, Solentia) (Figs 11, 12) which can be found in the skeletons of living and dead coral (Le Campion-Alsumard et al., 1995) and in other limestone substrata, contributing substantially to the dissolution of carbonates of coral reefs (Chazottes et al., 1996) and to the bioerosion of limestone coasts. Recent studies demonstrate a high diversity of endolithic cyanobacteria in shallow tropical and subtropical seas. Many new taxa, especially within the genus Hyella, have thus been described in the last 20 years, for example from the Bahamas, Florida and the Arabian Gulf (Golubic et al., 1996 and references cited therein).

Black-band disease is a widespread phenomenon found on coral reefs (Richardson, 1996). The disease consists of a microbial community dominated by the filamentous cyanobacterium Phormidium corallyticum (Rützler \& Santavy, 1983) associated with bacteria and fungi. It normally forms a band I mm thick between the coral skeleton and the living coral tissue. Black-band disease can cause the death of entire coral colonies due to tissue destruction as the bands migrate, and is thought to be a factor contributing to the observed global degradation of coral reefs (Williams \& Bunkley-Williams, 1990). 
A noteworthy feature of tropical regions, especially of coral reefs, is the presence of a number of cyanobacterial species belonging to the genera Aphanocapsa Nägeli, prochloron Lewin ex Florenzano et al., Synechocystis Sauvageau, Borzia and Oscillatoria, which live in symbiosis with sponges (Wilkinson, 1992) or ascidians (Pardy \& Royce, 1992). Recently, a new type of unicellular oxygenic photosynthetic prokaryote was isolated from a tropical colonial ascidian, Iissoclinum patella, and provisionally named Acaryochloris marina Miyashita et Chihara gen. et sp. inedit. (Miyashita et al., 1996). Its most distinctive feature is the presence of a unique light-harvesting system which uses chlorophyll $d$ as the major antenna pigment and chlorophyll $a$ as a minor pigment. Like other species commonly included in the Prochlorophyta (Goericke \& Repeta, 1992; Larkum et al., 1994), it also contains a chlorophyll $i$-like pigment (Miyashita et al., 1997) which is absent in cyanobacteria sensu stricto. Some of these organisms, especially Prochloron and Acaryochloris, are interesting models for the studies on the origin of the different algal plastid types (Lewin \& Cheng, 1989; Matthijs et al., 1994; Turner, 1997).

Coral reefs are one of the tropical marine habitats in which cyanobacterial diazotrophs appear to play a critical role in ecosystem functioning. Cyanobacteria are found in monospecific mats, mixed 'algal' turfs and as macroalgal epiphytes. Cyanobacteria play an important role in the nitrogen budget of coral reefs (Mague \& Holm-Hansen, 1975; Webb et al., 1975; Wiebe et al., 1975; Burris, 1976), where $\mathrm{N}_{2}$ fixation can account for $20-40 \%$ of the annual nitrogen requirements (Borowitzka \& Larkum, 1986). The estimated annual contribution of coral reefs to the global nitrogen cycle amounts to $2.8 \mathrm{Tg}$, with a mean areal $\mathrm{N}_{2}$ fixation rate of $25 \mathrm{~g} \mathrm{~m}^{-2}$ year $^{-1}$ (Capone \& Carpenter, 1982).

Although benthic cyanobacteria are periodically very common in reef habitats subject to high levels of herbivory, and although they lack structural defences (e.g. calcification) like various macroalgae, they seem to be a low-preference food item for many marine herbivores. Some of these cyanobacteria, such as the genera Hormothamnion Bornet et Flahaut (Pennings et al., 1997) and Lyngbya (Pennings et al., 1996; Nagle et al., 1996; Orjala \& Gerwick, 1996), are unpalatable to most, but not all, potential consumers, probably because of the presence of secondary metabolites which effectively deter feeding. Marine cyanobacteria have been a productive source of novel secondary metabolites (Moore, 1981; Faulkner, 1995) with varying bioactivities. They present a diversity of structural classes: cyclic peptides, depsipeptides, linear peptides, guanidines, phosphonates, purines, lipids and macrolides. They often contain nitrogen (in striking difference to those found in macroalgae) and often are halogenated (e.g. brominated pyrrole derivatives, chlorinated amides) (Moore, 1981). Some secondary metabolites from marine cyanobacteria have been examined for pharmacological activity (e.g. cytotoxicity to tumour cells, inhibition of proteases) (Shimizu, 1996). Sevcral bioactive peptides found in cyanobacteria have structural features of metabolites described from ascidians and sponges living in coral reefs (Namikoshi \& Rinehart, 1996), which suggests the latter compounds may be derived from dietary or symbiotic cyanobacteria (Williams et al., 1993), but transfer of genes cannot completely be ruled out (Shimizu, 1996).

One of the richest cyanobacterial source of secondary metabolites is the benthic filamentous I.ynghya majuscula Gomont (Mermaid hair) (Moore, 1981; Moore et al., 1984; Sitachitta \& Gerwick, 1998; Graber \& Gerwick, 1998; Hooper et al., 1998), one of the largest cyanobacteria known, which caused an outbreak of severe contact dermatitis in fishermen due to the presence of prenylated amino acid derivatives, called lyngbyatoxins (Cardellina et al., 1979). Another I.yngbya species, I. bouillonii, recently described from coral reefs in Papua New Guinea (Hoffmann \& Demoulin, 1991) where it forms extensive mats, strongly attached to madrepores in the infralittoral, proved also to be a rich source of novel macrolides and peptides (Klein et al., 1996, 1997, 1999). Hormothamnion enteromorphoides contains a series of at least 15 related cyclic peptides (Gerwick et al., 1989). Their chemical defences thus are probably a key factor allowing these cyanobacteria to persist in reefs.

\section{Planktonic cyanobacteria}

In contrast to their abundance in freshwater habitats, there are few truly planktonic cyanobacterial species in the sea. There are four groups of cyanobacteria known to be present in the plankton of tropical oceans in numbers sufficient to make a measurable ecological contribution: the picoplanktonic Synechococous and Prochlorococcus (see e.g. Ferris \& Palenik, 1998) and the filamentous genera Trichodesmium (Capone et al., 1997) and Richelia (Villareal, 1992) (Figs 16-20). There are, of course, many other reports of cyanobacteria of various genera (Sournia, 1970), such as Kalagnymene (Wille, 1904), but none of these seems to make a consistent major input into the ecosystem.

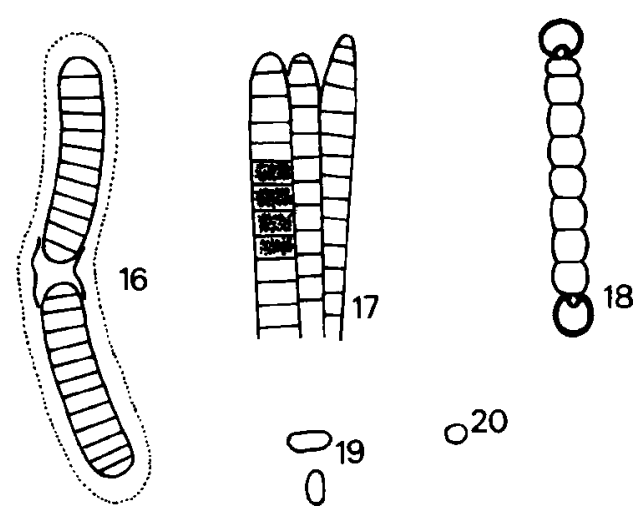

Figs 16-20. Representative cyanobacterial genera of the tropical marine plankton. Fig. 1ó. Katagnymene Lemmermann. Fig. 17. Trichodesmium: Ehrenberg ex Gomont. Fig. 18. Richelia Schmidt. Fig. 19. Synechococcus Nägeli. Fig. 20. Prochlorococcus Chisholm et al. 


\section{Trichodesmium}

During the past few decades, Trichodesmium has been one of the most intensively studied cyanobacteria of the open tropical oceans. The main reasons for this interest are that Trichodesmium can occur in great abundance (as surface blooms) and it can fix $\mathrm{N}_{2}$ (Dugdale et al., 1961) during the day without the formation of thick-walled heterocysts (Bergman \& Carpenter, 1991).

Trichodesmium includes a number of filamentous forms which, apart from their general tendency to aggregate in bundles, closely resemble species of Oscillatoria. Five marine species are included in the genus Trichodesmium, distinguished by trichome dimensions and colony morphology. On the basis of ultrastructure (Janson et al., 1995b), T. erythraeum Gomont and T. tenue Wille, with spherical colony shape and narrow trichomes, can be distinguished from T. thiebautii Gomont, T. hildebrandtii Gomont and T. contortum Wille. The presence of several distinct morphotypes is consistent with the results from nitrogenase nifH and $16 \mathrm{~S}$ rDNA sequence analyses (Capone et al., 1997), which also show that all Trichodesmium clones studied so far form a monophyletic group.

Species of Trichodesmium are primarily found in tropical and subtropical surface waters, especially during calm conditions. These waters have low nutrient concentrations and deep euphotic zones (Capone et al., 1997). Under calm conditions, filaments accumulate as surface blooms known to sailors as 'sea sawdust'. Such blooms are often large enough to be detected by satellite.

The positive buoyancy of Trichodesmium depends on the presence of very strong gas vesicles (Walsby, 1978), a possible adaptation to the great hydrostatic pressures to which Trichodesmium can be exposed at depth in the sea (e.g. about 20 bars at $200 \mathrm{~m}$ ). When highly gas-vacuolated, they can migrate to the surface at a velocity of $0.5-3 \mathrm{~mm}$ $\mathrm{s}^{-1}\left(40-250 \mathrm{~mm} \mathrm{day}^{-1}\right)$. In addition to providing buoyancy, the gas vacuoles may shield the cells from excessively strong radiation (Janson et al., 1995b).

Trichodesmium is well adapted to living in oligotrophic waters. It fixes atmospheric nitrogen, thus avoiding nitrogen limitation, and uses buoyancy reversals to migrate below the nutricline to acquire phosphorus (Carpenter \& Romans, 1991; Karl et al., 1992). In oligotrophic waters removed from terrestrial influences and unaffected by upwelling, where $\mathrm{N}_{2}$-fixing planktonic or benthic cyanobacteria are of importance, additional nutrient limitations may occur. In particular the availability of iron, essential for $\mathrm{N}_{2}$ fixation, $\mathrm{NO}_{3}{ }^{-}$assimilation and photosynthetic activity, may be restricted (Rueter et al., 1992; Paerl et al., 1994).

The enigmatic situation of having an oxygen-generating photosystem II functioning at the same time as the highly oxygen-sensitive process of nitrogen fixation is one of the most interesting traits of Trichodesmium. At least in certain Trichodesmium species, cells containing nitrogenase are clustered into groups (Janson et al., 1995b).
A recent model (Fredriksson \& Bergman, 1997) proposes (a) that Trichodesmium is capable of differentiating a cell type which is specific for nitrogenase; (b) that these nitrogenase-containing cells are grouped into small subsets, possibly one or more subsets in each filament; and (c) that these cells are structurally and functionally modified to harbour the oxygen-sensitive nitrogenase.

Trichodesmium aggregates often harbour diverse eukaryotic and prokaryotic organisms: bacteria, cyanobacteria, diatoms, dinoflagellates, fungi, protozoa, hydroids and copepods (O'Neil \& Roman, 1992; Siddiqui et al., 1992). The association of most organisms with Trichodesmium colonies appears to be mutualistic, but larger planktonic and nektonic organisms (fish, crabs) may graze on Trichodesmium filaments. There are also associations of the juvenile harpacticoid copepod Macrosetella gracilis with Trichodesmium. It not only ingests Trichodesmium colonies but rapidly incorporates cyanobacterial organic matter into its own cellular material (O'Neil, 1998). The neurotoxins identified for some Trichodesmium blooms (Hawser et al., 1991; Hawser \& Codd, 1992) may have a role in determining the susceptibility or resistance of Trichodesmium to grazers (Hawser et al., 1992).

A rapid disappearance of Trichodesmium blooms has been observed in the natural environment. Though the grazing action of zooplankton is considered a potential cause, recent observations (Ohki, 1997) suggest that Trichodesmium harbours a temperate virus leading to lysis. As for the picoplanktonic Synechococcus (Suttle \& Chan, 1994), viruses may play an important role in this component of the food web of the oligotrophic tropical ocean (Fuhrman \& Suttle, 1993).

There seems to be little doubt that Trichodesmium is the principal source of $\mathrm{N}_{2}$ fixation in marine pelagic ecosystems, contributing an estimated $80 \mathrm{Tg}$ (Capone et al., 1997) of fixed nitrogen per year, which could support up to half of the new production in oligotrophic oceans (Karl et al., 1997).

\section{Richelia intracellularis and other cyanobacteria-diatom symbioses}

Two types of cyanobacteria-diatom symbioses are common in the tropical marine plankton. The most frequently reported is the association of the heterocystous filamentous cyanobacterium generally referred to as Richelia intracellularis Schmidt (Nostocaceae) with the diatom genera Rhizosolenia, Hemiaulus, Bacteriastrum and Chaetoceros (Villareal, 1992). Besides $R$. intracellularis, an additional taxon, Calothrix rhizosoleniae (Rivulariaceae), was described by Lemmermann (1905). The similarity of the two symbionts may have led to misidentifications and it would be interesting to establish their genetic relationship. $R$. intracellularis has short unbranched filaments with heterocysts at one end or, less commonly, both ends. There are usually two to four filaments per diatom cell but the number increases with the size of the host (up to 32 ; 
Sundström, 1984). The cyanobiont is usually located at the apex of the host Rhizosolenia cell outside the host cytoplasm and there is no evidence for the presence of gas vesicles (Janson et al., 1995a). The filament breaks into two halves, one half migrating into each daughter cell (Taylor, 1982). The division cycles of the diatom host and of the Richelia symbiont seem to be largely uncoupled (Villareal, 1989).

Richelia is primarily found in warm tropical and subtropical waters, with a latitudinal range from approximately $38^{\circ} \mathrm{N}$ to $36^{\circ} 30^{\prime} \mathrm{S}$ (Sournia, 1970; Villareal, 1992). Its abundance varies with season, being low in winter (10 cells $\left.1^{-1}\right)$ and high in late summer $\left(10^{4}\right.$ cells $\left.\mathrm{l}^{-1}\right)$ in the central North Pacific gyre (Venrick, 1974).

Together with Trichodesmium these intracellular diatom cyanobionts contribute to nitrogen fixation in oligotrophic tropical oceans (Mague et al., 1974; Venrick, 1974; Carpenter \& Romans, 1991). Nitrogenase is found only in heterocysts in Richelia and nitrogen is fixed during the day with rates ranging up to $18 \mathrm{mg} \mathrm{N} \mathrm{m}^{-2}$ day $^{-1}$, supporting up to $36 \%$ of total phytoplankton production during some blooms (Sellner, 1997).

A second type of symbiosis occurs between unicellular, coccoid cyanobacteria and the diatom genus Neostreptotheca, an association for which few data are available (Villareal, 1992).

\section{Synechococcus and Prochlorococcus}

Picoplanktonic cyanobacteria are an important component of the marine plankton community (e.g. Ferris \& Palenik, 1998). Biomass and photosynthesis measurements in different tropical and equatorial oceans show that the bulk of the chlorophyll $a$ is in organisms of less than $1 \mu \mathrm{m}$ and $3 \mu \mathrm{m}$ respectively, and that this contributes $20-90 \%$ of the photosynthetic productivity (e.g. tropical North Atlantic: Platt et al., 1983; eastern tropical Pacific Ocean: Li et al., 1983; subtropical Hawaiian waters: Takahashi \& Bienfang, 1983). These cyanobacteria are an important food source for planktonic heterotrophic flagellates and ciliates, as well as macroinvertebrates (Yahel et al., 1998).

The two important picoplanktonic groups are Synechococcus, discovered 20 years ago (Waterbury et al., 1979; Johnson \& Sieburth, 1979), and Prochlorococcus (Chisholm et al., 1988; Chisholm et al., 1992), identified 10 years ago. Prochlorococcus is a unicellular oxygenic photosynthetic prokaryote that contains divinyl chlorophyll $b$ as its main pigment (Goericke \& Repeta, 1992) rather than the phycobiliproteins typical of cyanobacteria. At least two ecotypes, adapted to grow at either low or high light intensities, can be distinguished (Moore et al., 1998).

While the coccoid Synechococcus is virtually ubiquitous in all marine environments, ranging in abundance over three orders of magnitude from 500 to 500000 cells ml$^{-1}$, Prochlorococcus is virtually ubiquitous in the latitudinal band $40^{\circ} \mathrm{N}-40^{\circ} \mathrm{S}$ where it comprises a significant proportion of the photosynthetic biomass (Campbell et al., 1994). North of $40^{\circ} \mathrm{N}$ and south of $40^{\circ} \mathrm{S}$ it can still be found but its concentrations decline fairly rapidly (Partensky et al., 1999). It is found throughout the photic zone, but in contrast to Trichodesmium often dominates the deep chlorophyll maximum at densities of $10^{4}-10^{5}$ cells $\mathrm{ml}^{-1}$ (Post \& Bullerjahn, 1994). It was suggested (Vaulot et al., 1995) that, in contrast to Synechococcus, Prochlorococcus may not be severely limited by nutrients, including iron.

\section{Geographical distribution of tropical cyanobacteria}

The study of the distribution of cyanobacteria is hampered by difficulties in recognizing the different taxa due to their simple morphology. To date, only floristic lists using the traditional geitlerian approach and Drouet's system (Drouet, 1981) (e.g. Humm \& Wicks, 1980; Zaneveld, 1988) have appeared in the literature. However, it has been shown that the latter system does not reflect the natural cyanobacterial diversity (e.g. Stam, 1978; Waterbury \& Stanier, 1978). The main identification guide is still Geitler (1930-2), which mostly deals with taxa described from temperate regions. Many taxonomists working on tropical collections and encountering populations which did not correspond well to any described species often simply referred these to the most similar taxon known from temperate regions (Komárek, 1985). Such misinterpretations led to an overestimate of the distribution area of many species originally described from temperate zones. This situation will improve with the new edition of the Süsswasserflora von Mitteleuropa, which also includes non-European species as is already the case in the first published part treating the unicellular cyanobacteria (Komárek \& Anagnostidis, 1999). Notwithstanding these methodological difficulties, it seems that apart from cyanobacterial species with a (sub)cosmopolitan distribution (e.g. Lyngbya aestuarii, Microcoleus chthonoplastes Gomont), as confirmed by a phenotypic and phylogenetic analysis of $M$. chthonoplastes by Garcia-Pichel et al. (1996), some seem to be limited almost exclusively to warmwater regions (e.g. the planktonic genera Trichodesmium (Capone et al., 1997) and Prochloroccus (Partensky et al., 1999) and the benthic genera Prochloron (Lewin \& Cheng, 1989). Herpyzonema and Hormothamnion (Hoffmann, 1993)). The distribution of these taxa suggests that temperature is probably a major factor limiting their distribution (Hoffmann, 1994). This has been confirmed by culture studies, for example, of two clones of the genus Prochlorococcus that showed minimum growth temperatures of 15 and $12.5^{\circ} \mathrm{C}$, respectively (Moore et al., 1995). In the same way, the growth and activity of the genus Trichodesmium, which is occasionally found in waters colder than $20^{\circ} \mathrm{C}$, are usually restricted to waters above $20{ }^{\circ} \mathrm{C}$ (Capone et al., 1997).

\section{Conclusions}

As photosynthetic organisms, cyanobacteria sensu lato are important contributors to benthic and open ocean primary production, but their main role in tropical marine ecosystems appears to be as nitrogen fixers. Of primary 
importance in the often oligotrophic tropical oceans is the non-heterocystous, planktonic bloom-forming Trichodesmium. $\mathrm{N}_{2}$ fixation associated with Trichodesmium probably represents a major nitrogen source to the marine and global nitrogen cycle. Tropical marine ecosystems are characterized by a specific cyanobacterial flora and nature seems to have provided all possible combinations of photosynthetic pigments, thus presenting interesting model systems for the study of the evolution of plastids. The largely unknown biodiversity, especially in the less accessible infralittoral, may also in the future be an important renewable source for hitherto undescribed bioactive compounds, some of which may have potential as antibiotics, antitumour agents and related pharmaceuticals (Rossi et al., 1997).

\section{Acknowledgements}

The author is a research associate of the Belgian National Fund for Scientific Research whose financial support is also acknowledged in the framework of FRFC grants $2.9006 .86,2.9001 .90$ and 2.4521 .96 which allowed the author, in cooperation with professor V. Demoulin, to get acquainted with the tropical marine cyanobacteria of Papua New Guinea.

\section{References}

BAuld, J., D' Amelio, E. \& FARMER, J.D. (1992). Modern microbial mats. In The Proterozoic Biosphere (Schopf, J.W. \& Klein, C., editors), 26́1-269. Cambridge University Press, Cambridge.

Bergman, B. \& Carpenter, E.J. (1991). Nitrogenase confined to randomly distributed trichomes in the marine cyanobacterium Trichodesmium thiebautii. J. Phycol, 27 : 158-165.

BorowitzKa, M.A. \& Larkum, A.W.D. (1986). Reef algae. Oceanus, 29: $49-54$.

Brouns, J.J.W.M. \& Heis, F.M.L. (1986). Production and biomass of the seagrass Enhahus acoroides (L.f.) Royle and its epiphytes. Aquat. Bot., 25 : $21-45$.

BuRRIS, R.H. (1976). Nitrogen fixation by blue-green algae of the Lizard Island area of the Great Barrier Reef. Aust. J. Plant Physiol, 3: 41-51.

Campbell, L., Nolla, H.A. \& Vaulot, D. (1994). The importance of Prochlorococcus to community structure in the Central North Pacific Ocean. Limnol. Oceanogr., 39: 954-96I.

Capone, D.G. \& Carpenter, E.J. (1982). Nitrogen fixation in the marine environment. Science, 217 : 1140-1142.

Capone, D.G., Zehr, J.P., Paerl, H.W., Bergman, B. \& Carpenter, E.J. (1997). Trichodesmium, a globally significant marine cyanobacterium. Science, 276: 1221-1229.

Cardellina, J.H., Marner, F.J, Moore, R.E. (1979). Seaweed dermatitis: structure of lyngbyatoxin A. Science, $204:$ 193-195.

CARPenter, E.J. \& ROMAns, K. (1991). Major role of the cyanobacterium Trichodesmitum in nutrient cycling in the North Atlantic Ocean. Science, 254: $1356-1358$.

Castenholz, R.W. (1992). Species usage, concept, and evolution in the cyanobacteria (blue-green algae). J. Phycol., 28 : 737-745.

Chazottes,V., Le Campion-Alsumard, T. \& Peyrot-Clauusade, M. (1996). Bioerosion rates on reefs: interaction between microborers, macroborers and grazers (Moorea, French Polynesia). Palaeogeogr. Palaeoclimatol. Palaeoecol, 113: 189-198.

Chisholm, S.W., Olson, R.J., Zettler, E.R., Waterbury, J., Goericke, R. \& WeLSCHMEYFR, N. (1988). A novel free-living prochlorophyte occurs at high cell concentrations in the oceanic euphotic zone. Nature, 334 : 340-343.

Chisholm, S.W., Frankel, S.L., Goericke, R., Olson, R.J., Palenik, B., Waterbury, J.B., West-Johnsrud, L. \& Zettier, E.R. (1992). Prochlorococcus marinus nov. gen. nov. sp.: an oxyphototrophic marine prokaryote containing divinyl chlorophyll $a$ and $b$. Arch. Microbiol., 157:297-300.

Droute, F. (1981). Revision of the Stigonemataceae with a summary of the classification of the blue-green algae. Beih. Nova Hedwigia, 66: 1-221.

Dugdale, R.C., Menzel, D.W. \& Ryther, J.H. (1961). Nitrogen fixation in the Sargasso Sea. Deep Sea Res., 7: 298-300.

FAulKNeR, D.J. (1995). Marine natural products. Nat. Prod. Rep., 12 : 223-269. FerRIS, M.J. \& PALENIK, B. (1998). Niche adaptation in ocean cyanobacteria. Nature, 396: 226-228.

FoGG, G.E. (1982). Marine plankton. In The Biology of Cyanobacteria (Carr, N.G. \& Whitton, B.A., editors), 491-513. Blackwell Scientific, Oxford.

FredRIKSSON, C. \& BeRGMAN, B. (1997). Ultrastructural characterisation of cells specialised for nitrogen fixation in a non-heterocystous cyanobacterium, Trichodesmium spp. Protoplasma, 197: 76-85.

FunRman, J.A. \& Suttle, C.A. (1993). Viruses in marine planktonic systems. Oceanography, 6: 51-63.

Garcia-Pichel, F. \& Castenholz, R.W. (1991). Characterization and biological implications of scytonemin, a cyanobacterial sheath pigment. $J$. Phycol, 2 7 : 395-409.

Garcia-Pichel, F., Prufert-Bebout, L. \& Muyzer, G. (1996). Phenotypic and phylogenetic analyses show Microcoleus chthonoplastes to be a cosmopolitan cyanobacterium. Appl. Environ. Microbiol, 62 : 3284-3291.

Geitler, L. (1930-2). Cyanophyceae. In Kryptogamen-Fiora von Deutschland, Österreich und der Schweiz (Rabenhorst, L., editor), vol. 14, 1-1196. Akademische Verlagsgesellschaft, Leipzig.

Gerwick, W.H., Mrozek, C., Moghaddam, M.F. \& Agrarwal, S.K. (1989). Novel cytotoxic peptides from the tropical marine cyanobacterium $H$. enteromorphoides. I. Discovery, isolation and initial chemical and biological characterization of the hormothamnins from wild and cultured material. Experientia, 45 : 115-121.

Goericke, R. \& RepetA, D.J. (1992). The pigments of Prochiorococcus marinus the presence of divinyl chlorophyll $a$ and $b$ in a marine prokaryote. Limnol. Oceanogr., 37 : 425-433.

GoluBic, S. (1973). The relationship between blue-green algae and carbonate deposits. In The Biology of Bite-Green Algae (Carr, N.G. \& Whitton, B.A., editors), 434-472. Blackwell Scientific, Oxford.

GoluBic, S. (1985). Microbial mats and modern stromatolites in Shark Bay, Western Australia. In Pianetary Ecology (Caldwell, D.E., Brierley, J.A. \& Brierley, C.L., editors), 3-16. Van Nostrand Reinhold, New York.

Golubic, S. \& Browne, K.M. (1996). Schizothrix gebeleinii sp. nova builds subtidal stromatolites, Lee Stocking Island, Bahamas. Arch. Hydrobiol. Suppl., 117 (Algol. Stud., 83): 273-290.

Golubic, S. \& Focke, J.A. (1978). Phormidium hendersonii Howe: identity and significance of a modern stromatolite building microorganism. J. Sed. Petrol, 48 : $751-754$.

Golubic, S. \& KNoll, A.H. (1993). Prokaryotes. In Fossil Prokaryotes and Protists (Lipps, J.H., editor), 51-76. Blackwell Scientific, Oxford.

Golubic, S., Al-Thukair, A.A. \& Gektidis, M. (1996). New euendolithic cyanobacteria from the Arabian Gulf and the Bahama Bank: Solentia sanguinea sp. nova. Arch. Hydrobiol. Suppl., 117 (Algol. Stud,, 83): 29I-30I.

Graber, M.A. \& Gerwick, W.H. (1998). Kalkipyrone, a toxic gamma-pyrone from an assemblage of the marine cyanobacteria Lyngbya majuscula and Tolypothrix sp. J. Nat. Prod., 61: 677-680.

HAWSER, S.P. \& CODD, G.A. (1992). The toxicity of Trichodesmium blooms for Caribbean waters. In Marine Pelagic Cyanobacteria: Trichodesmium and Other Diazotrophs (Carpenter, E.J., Capone, D.G. \& Rueter, J.G., editors), 319-329. Kluwer Academic, Dordrecht.

Hawser, S.P., Codd, G.A., Capone, D.G. \& Carpenter, E.J. (1991). A neurotoxic factor associated with the bloom-forming cyanobacterium Trichodesmium. Toxicon, 29:277-278.

Hawser, S.P., O'Neil, J.M., Roman, M.R. \& Codd, G.A. (1992). Toxicity of blooms of the cyanobacterium Trichodesmium to zooplankton. J. Appl. Phycol, 4: 79-86.

HoffMAN, E.J. (1985). Distribution patterns of recent microbial endoliths in the intertidal and supratidal zones, Bermuda. In Biogenic Structures: Their Use in Interpreting Depositional Environments (Curran, H.A., editor). Soc. Econ. Paleontol. Mineral. Spec. Publ. 35: 179-194.

Hofrmann, L. (1989). Les Cyanophycées marines et terrestres de Papouasie Nouvelle-Guinée: inventaire taxonomique et systématique expérimentale. $\mathrm{PhD}$ thesis, University of Liège.

Hoffmann, L. (1993). Marine Cyanophyceae of Papua New Guinea. V. 
Nostocales (except Rivulariaceae) and Stigonematales. Nova Hedwigia, 57:393-408

Hoffmann, L. (1994). Biogeography of marine blue-green algae. Arch. Hydrobiol. Suppl, 105 (Alool. Stud., 75) : 137-148.

Hoffmann, L. \& Demoulin, V. (1991). Marine Cyanophyceae of Papua New Guinea. II. Lyngbya bouillonii sp. nov, a remarkable tropical reef-inhabiting blue-green alga. Belg. J. Bot., $124: 82-88$.

Hoffmann, L. \& Demoulin, V. (1993). Marine Cyanophyceae of Papua New Guinea. III. The genera Borzia and Oscillatoria. Bot. Mar., 36: 451-459.

Hooper, G.J., Orjala, J., Schatzman, R.C. \& Gerwick, W.H. (1998). Carmabins $A$ and $B$, new lipopeptides from the Caribbean cyanobacterium Lyngbya majuscula. J. Nat. Prod., 61:529-533.

Humm, H.J. \& WICKS, S.R. (1980). Introduction and Guide to the Marine Bluegreen Algae. Wiley, New York.

Hussain, M.I. \& КнолA, T.M. (1993). Intertidal and subtidal blue-green algal mats of open and mangrove areas in the Farasan Archipelago (Saudi Arabia), Red Sea. Bot. Mar., 36:377-388.

JANSON, S., RAI, A.N. \& BERGMAN, B. (1995a). Intracellular cyanobiont Richelia intracellularis: ultrastructure and immuno-localisation of phycoerythrin, nitrogenase, rubisco and glutamine synthetase. Mar. Biol, 124: 1-8.

Janson, S., Siddigui, P.J.A., Walsby, A.E., Romans, K.M., Carpenter, E.J. \& BeRgman, B. (1995b). Cytomorphological characterisation of the planktonic diazotrophic cyanobacteria Trichodesmium spp. from the Indian Ocean, Caribbean and Sargasso Seas. J. Phycol, 31: 463-477.

Johnson, P.W. \& SiebURTh, J.McN. (1979). Chroococcoid cyanobacteria in the sea: ubiquitous and diverse phototrophic biomass. Limnol. Oceanogr. 24: 928-935

Karl, D.M., Letelier, R., Hebel, D.V., Bird, D.F. \& WinN, C.D. (1992). Trichodesmium blooms and new nitrogen production in the North Pacific gyre. In Marine Pelagic Cyanobacteria: Trichodesmium and Other Diazotrophs (Carpenter, E.J., Capone, D.G. \& Rueter, J.G., editors), 219-237. Kluwer Academic, Dordrecht.

Karl, D., Letelier, R., Tupas, L., Dore, J., Christians, J. \& Hebel, D. (1997). The role of nitrogen fixation in biogeochemical cycling in the subtropical North Pacific Ocean. Nature, 388 : 533-538.

Klein, D., Braekman, J.C., Daloze, D., Hoffmann, L. \& Demoulin, V. (1996). Laingolide, a novel 15-membered macrolide from Lyngbya bouillonii (Cyanophyceae). Tetrahedron Lett., 37: 7519-7520.

Klein, D., Braekman, J.C., Daloze, D., Hoffmann, L. \& Demoulin, V. (1997). Lyngbyaloside, a novel 2,4,4-tri-O-methyl-6-deoxy-alpha-mannopyroside macrolide from Lyngbya bouillonii (Cyanobacteria). J. Nat. Prod., $60: 1057-1059$.

Klein, D., Braekman, J.C., Daloze, D., Hoffmann, L., Castillo, G. \& Demoulin, V. (1999). Lyngbyapeptin $A$, a modified tetrapeptide from Lyngbya bouillonii (Cyanophyceae). Tetrahedron Lett., 40 : 695-696.

Klumpr, D.W., Saltta-Espinosa, J.S. \& Fortes, M.D. (1992). The role of epiphytic periphyton and macroinvertebrate grazers in the trophic flux of a tropical seagrass community. Aquat. Bot., 43:327-349.

KoMÁREK, J. (1985). Do all cyanophytes have a cosmopolitan distribution? Survey of the freshwater cyanophyte flora of Cuba. Arch. Hydrobiol. Suppl 71 (Algol. Studies, 38/39): 359-386.

KomÁreK, J. \& ANAGNostidis, K. (1999). Cyanoprokaryota. 1. Chroococcales. In Süsswasserflora von Mitteleuropa (Ettl, H., Gärtner, G., Heynig, H. \& Mollenhauer, D., editors), vol. 19. Gustav Fischer, Jena.

larkum, A.W.D., Scaramuzzi, C., Cox, C., Hiller, R.G. \& Turner, A.G. (1994). Light-harvesting chlorophyll-c like pigment in Prochloron. Proc. Natl. Acad. Sci. USA, 91: 679683.

Le Campion-Alsumard, T. (1979). Les Cyanophycées endolithes: systématique, ultrastructure, écologie et biodestruction. Oceanol. Acta, 2: 143-156.

Le Campion-Alsumard, T., Golubic, S. \& Hutchings, P. (1995). Microbial endoliths in skeletons of live and dead corals: Porites lobata (Moorea, French Polynesia). Mar. Ecol. Progr. Ser, 117: 149-157.

Lemmermann, E. (1905). Die Algenflora der Sandwich-Inseln. Ergebnisse einer Reise nach dem Pacifik, H. Schauinsland 1896/97. Englers Bot. Jahrb., $34: 607-663$.

Lewin, R.A. \& Cheng, L. (editors) (1989). Prochloron: A Microbial Enigma. Chapman and Hall, New York.

LI, W.K.W., Subba Rao, D.V., Harrison, W.G., Smith, J.C., Cullen, J.J., Irwin, B. \& PLATT, T. (1983). Autotrophic picoplankton in the tropical ocean. Science, 219: 292-295.
Mague, T.H. \& Holm-Hansen, O. (1975). Nitrogen fixation on a coral reef. Phycologia, 14: 87-92.

Mague, T.H., Weare, N.M. \& Holm-Hansen, O. (1974). Nitrogen fixation in the North Pacific Ocean. Mar. Biol, 24: 109-119.

Matthis, H.C.P., van der Staay, G.W.M. \& Mur, L.R. (1994). Prochlorophytes: the 'other' cyanobacteria? In The Molecular Biology of Cyanobacteria (Bryant, D.A., editor), 49-64. Kluwer Academic, Dordrecht.

Miyashita, H., Ikemoto, H., Kurano, N., Adachi, K., Chihara, M. \& MrYACHI, S. (1996). Chlorophyll $d$ as a major pigment. Nature, 383: 402.

Mryashita, H., Adachi, K., Kurano, N., Ikemoto, H., Chimara, M. \& MrYACHI, S. (1997). Pigment composition of a novel oxygenic photosynthetic prokaryote containing chlorophyll $d$ as the major chlorophyll. Plant Cell Physiol, $38: 274-281$.

Moncreiff, C.A., Sullivan, M.J. \& Daehnick, A.E. (1992). Primary production dynamics in seagrass beds of Mississippi Sound: the contributions of seagrass, epiphytic algae, sand microflora, and phytoplankton. Mar. Ecol. Progr. Ser, 87: 161-171.

Moore, L.R., Goericke, R. \& CHISHolm, S.W. (1995). Comparative physiology of Symechococcus and Prochlorococcus: influence of light and temperature on growth, pigments, fluorescence and absorptive properties. Mar. Ecol. Progr. Ser., 116: 259-275.

Moore, L.R., RocAP, G. \& CHISHOLm, S.W. (1998). Physiology and molecular phylogeny of coexisting Prochlorococcus ecotypes. Nature, 393: 464-467.

MooRE, R.E. (1981). Constituents of blue-green algae. In Marine Natural Products: Chemical and Biological Perspectives (Scheuer, P.J., editor), vol. 4, I-52. Academic Press, New York.

Moore, R.E., Blackman, A.J., Cheuk, C.E., Mynderse, J.S. \& Matsumoto, G.K. (1984). Absolute stereochernistries of the aplysiatoxins and oscillatoxin A. J. Org. Chem, $49: 2484-2489$

MuKaI, H. \& IIIMA, A (1995). Grazing effects of a gammaridean Amphipoda, Ampithoe sp., on the seagrass, Syringodium isoetifolium, and epiphytes in a tropical seagrass bed of Fiji. Ecol. Res., 10: 243-257.

MurRAY, R.G.E. (1989). The higher taxa, a place for everything...? In Bergey's Mantul for Systematic Bacteriology (Staley, J.T., editor), vol. 3, 1631-1634. Williams and Wilkins, Baltimore.

NAgLe, D.G., PAUL, V.J. \& RoberTs, M.A. (1996). Ypaomide, a new broadly acting feeding deterrent from the marine cyanobacterium Lyngbya majuscula. Tetrahedron Lett., 37: 6263-6266.

NAmikoshI, M. \& RineHART, R.L. (1996). Bioactive compounds produced by cyanobacteria. J. Ind. Microbiol, 17: 373-384.

Онкг, K. (1997). A possible role of temperate virus(es) in the regulation of Trichodesmium biomass. In Book of Abstracts: International Symposium on Marine Cyanobacteria and Related Organisms, Institut Océanographique, Paris, p. 26.

O'NeIL, J.M. (1998). The colonial cyanobacterium Trichodesmium as a physical and nutritional substrate for the harpacticoid copepod Macrosetella gracilis. J. Plankton Res, $20: 43-59$.

O'NeiL, J.M. \& Roman, M.R. (1992). Grazers and associated organisms of Trichodesmium. In Marine Pelagic Cyanobacteria: Trichodesmium and other Diazotrophs (Carpenter, E.J., Capone, D.G. \& Rueter, J.G., editors), 61-73. Kluwer Academic, Dordrecht.

OriaLA, J. \& GeRWICK, W.H. (1996). Barbamide, a chlorinated metabolite with molluscidal activity from the Caribbean cyanobacterium Lyngbya majuscula. J. Nat. Prod., 59: 427-430.

Paerl, H.W., Prufert-Bebout, L.E. \& Guo, C.Z. (1994). Iron-stimulated $N_{2}$ fixation and growth in natural and cultured populations of the planktonic marine cyanobacteria Trichodesmium spp. Appl. Environ. Microbiol, 60: 1044-1047.

PARDY, R.L. \& RoYCE, C.L. (1992). Ascidians with algal symbionts. In Algae and Symbioses (Reisser, W., editor), 215-230. Biopress, Bristol.

Partensky, F., Hess, W.R. \& Vaulot, D. (1999). Prochlorococcus, a marine photosynthetic prokaryote of global significance. Microb. Mol. Biol. Rev., 63: 106-127.

Pennings, S.C., Weiss, A.M. \& PAul, V.J. (1996). Secondary metabolites of the cyanobacterium Microcoleus lyngbyaceus and the sea hare Stylocheilus longicauda: palatability and toxicity. Mar. Biol., 126: 735-743.

Pennings, S.C., Pablo, S.R. \& Paul, V.J. (1997). Chemical defenses of the tropical, benthic marine cyanobacterium Hormothamnion enteromorphoides: diverse consumers and synergisms. Limnol. Oceanogr., 42: 911-917.

Perkins, R.D. \& Tsentas, C.I. (1976́). Microbial infestation of carbonate 
substrates planted on the St Croix Shelf, West Indies. Geol. Soc. Am. Bull., 87: 1615-1628.

Philups, A., Lambert, G., Granger, J.E. \& Steinke, T.D. (1996). Vertical zonation of epiphytic algae associated with Avicennia marina (Forssk.)Vierh. pneumatophores at Beachwood Mangroves Nature Reserve, Durban, South Africa. Bot. Mar., 39: 167-175.

PhL.IPS, E.J., Willis, M. \& Verchick, A. (1986). Aspects of nitrogen fixation in Sargassum communities off the coast of Florida. J. Exp. Mar. Biol. Ecol, 102 : 99-119

Platt, T., Subba Rao, D.B. \& Irwin, B. (1983). Photosynthesis of picoplankton in the oligotrophic ocean. Nature, 301: 702-704.

Post, A.F. \& Bullerjahn, G.S. (1994). The photosynthetic machinery of Prochlorophytes: structural properties and ecological significance. FEMS Microbiol. Rev., 13: 393-414.

Poттs, M. (1979). Nitrogen fixation (acetylene reduction) associated with communities of heterocystous and non-heterocystous blue-green algae in mangrove forests of Sinai. Oecologia, 39:359-373.

Poтts, M. (1980). Blue-green algae (Cyanophyta) in marine coastal environments of the Sinai Peninsula: distribution, zonation, stratification and taxonomic diversity. Phycologia, 19: 60-73.

PotTs, M. \& Whitтon, B.A. (1980). Vegetation of the intertidal zone of the lagoon of Aldabra, with particular reference to the photosynthetic prokaryotic communities. Proc. R. Soc. Lond, Ser. B, 208: 13-55.

Radtke, G., Le Campion-Alsumard, T. \& Golubic, S. (1996). Microbial assemblages of the bioerosional 'notch' along tropical limestone coasts. Arch. Hydrobiol. Suppl, 117 (Algol. Stud. 83): 469-482.

RadtKe, G., Le Campion-Alsumard, T. \& Golubic, S. (1997). Microbial assemblages involved in tropical coastal bioerosion: an Atlantic-Pacific comparison. In Proc. 8th Int. Coral Reef Symp., 2 : 1825-1830.

RichARDSON, L.L. (1996). Horizontal and vertical migration patterns of Phormidium corallyticum and Beggiatoa spp. associated with black-band disease of corals. Microb. Ecol, 32: 323-335.

Rossi, J.V., RoberTs, M.A., Yoo, H.D. \& Gerwick, W.H. (1997). Pilot scale culture of the marine cyanobacterium Lyngbya majuscula for its pharmaceutically-useful natural metabolite curacin A. J. Appl. Phycol, 9: 195-204.

Rueter, J.G., Hutchins, D.A., SMith, R.W. \& Unsworth, N.L. (1992). Iron nutrition of Trichodesmizm. In Marine Pelagic Cyanobacteria: Trichodesmium and other Diazotrophs (Carpenter, E.J., Capone, D.G. \& Rueter, J.G., editors), 289-306. Kluwer Academic, Dordrecht.

RützleR, K. \& SANTAVY, D.L. (1983). The black band disease of Atlantic corals. I. Description of the cyanophyte pathogen. Publ. Staz. Zool. Napoli (Italia) Mar. Ecol, 4: 301-319.

SelLnER, K.G. (1997). Physiology, ecology, and toxic properties of marine cyanobacterial blooms. Limnol. Oceanogr., 42 : 1089-1104.

SHERIDAN, R.P. (199I). Epicaulous, nitrogen-fixing microepiphytes in a tropical mangal community, Guadeloupe, French West Indies. Biotropica, 23: 530-541.

Shimizu,Y. (1996). Microalgal metabolites: a new perspective. Annu. Rev. Microbiol, 50: 431-465.

Siddiqui, P.J.A., Carpenter, E.J. \& Bergman, B. (1992). Trichodesmium: ultrastructure and protein localization. In Marine Pelagic Cyanobacteria: Trichodesmium and other Diazotrophs (Carpenter, E.J., Capone, D.G. \& Rueter, J.G., editors), 9-28. Kluwer Academic, Dordrecht.

SitAChitta, N. \& Gerwick, W.H. (1998). Grenadadiene and grenadamide, cyclopropyl-containing fatty acid metabolites from the marine cyanobacterium Lyngbya majuscula. J. Nat. Prod., 61: 681-684.

SourniA, A. (1970). Les Cyanophycées dans le plancton marin. Ann. Biol, 9: $63-76$.

SourNIA, A. (1976). Ecologie et productivité d'une Cyanophycée en milieu corallien: Oscillatoria limosa Agardh. Phycologia, 15 : 363-366.

ST AM, W. (1978). A taxonomic study of a number of blue-green algal strains (Cyanophyceae) based on morphology, growth and deoxyribonucleic acid homologies. $\mathrm{PhD}$ thesis, University of Groningen.

Stephenson, T.A. \& Stephenson, A. (1949). The universal features of zonation between tidemarks on rocky shores. J. Ecol, 37: 289-305.

Sundström, B.G. (1984). Observations on Rhizosolenia clevei Ostenfeld (Bacillariophyceae) and Richelia intracellularis Schmidt. Bot. Mar, 27 : $345-355$.

Suttle, C.A. \& Chan, A.M. (1994). Dynamics and distribution of cyanophages and their effect on marine Synechococcus spp. Appl. Environ. Microbiol, $60: 3167-3174$
TAKAHASH, M. \& BIENFANG, P.K. (1983). Size structure of phytoplankton photosynthesis in subtropical Hawaiian waters. Mar. Biol, 76: 203-211.

Taton, A. \& Hofrmann, L. (1999). Distribution patterns of blue-green algal endoliths in the intertidal and supratidal zones of Papua New Guinea. Arch. Hydrobiol. Suppl. 129 (Algol. Stud. 94): 353-363.

TAYLOR, F.J.R. (1982). Symbioses in marine microplankton. Ann. Inst. Océanogr., 58S: 61-90.

TAYLOR, J.D. (1968). Coral reef and associated invertebrate communties (mainly molluscan) around Mahé, Seychelles. Phil. Trans. R. Soc. B, 254 129-206.

Toledo, G., Bashan, Y. \& Solldner, A. (1995). Cyanobacteria and black mangroves in Northwestern Mexico: colonization, and diurnal and seasonal nitrogen fixation on aerial roots. Can. J. Bot., 41 : 999-1011.

TURNER, S. (1997). Molecular systematics of oxygenic photosynthetic bacteria. Plant Syst. Evol. Suppl, 11: 13-52.

VAN DEN HOEK, C. (1984). World-wide latitudinal and longitudinal seaweed distribution patterns and their possible causes, as illustrated by the distribution of Rhodophytan genera. Helgol. Wiss. Meeresunters, 38 : 227-257.

VAUlot, D., Marie, D., Olson, R.J. \& ChISHOLM, S.W. (1995). Growth of Prochlorococcus, a photosynthetic prokaryote, in the equatorial Pacific ocean. Science, 268 : 1480-1482.

VenRICK, E.L. (1974). The distribution and significance of Richelia intracellularis Schmidt in the North Pacific Central Gyre. Limnol. Oceanogr., 19: 437-445

Villareal, T.A. (1989). Division cycles in the nitrogen-fixing Rhizosolenia (Bacillariophyceae)-Richelia (Nostocaceae) symbiosis. Br. Phycol. J., 24: 357-365.

VILLAREAL, T.A. (1992). Marine nitrogen-fixing diatom-cyanobacteria symbioses. In Marine Pelagic Cyanobacteria: Trichodesmium and other Diazotrophs (Carpenter, E.J., Capone, D.G. \& Rueter, J.G., editors), 163-175. Kluwer Academic, Dordrecht.

WALSBY, A.E. (1978). The properties and buoyancy-providing role of gas vacuoles in Trichodesmitum Ehrenberg. Br. Phycol. J., 13: 103-11ó.

WALTER, M.R. (editor) (1976). Stromatolites. Elsevier, Amsterdam.

WATERBURY, J.B. \& StANIER, R.Y. (1978). Patterns of growth and development in pleurocapsalean cyanobacteria. Bacteriol. Rev., 42: 2-44.

WATERBURY, J.B., WATSON, S.W., GUILLARD, R.R. \& BRAND, L.E. (1979). Widespread occurrence of a unicellular marine plankton cyanobacteria. Nature, 277: 293-294.

WebB, K.L., DuPaul, W.D., Wiebe, W., Sottile, W. \& Johannes, R.E. (1975). Enewetak (Eniwetok) Atoll: aspects of the nitrogen cycle on a coral reef. Limol. Oceanogr., 20 : 198-210.

Whitton, B.A. \& Potts, M. (1982). Marine littoral. In The Biology of Cyanobacteria (Carr, N.G. \& Whitton, B.A., editors), 515-542. Blackwell Scientific, Oxford.

WieBe, W.J., JohanNes, R.E. \& WEBB, K.L. (1975). Nitrogen fixation in a coral reef community. Science, $\mathbf{1 8 8}: 257-259$.

WILKINSON, C.R. (1992). Symbiotic interactions between marine sponges and algae. In Algae and Symbioses (Reisser, W., editor), 112-151. Biopress, Bristol.

WILLE, N. (1904). Die Schizophyceen der Plankton-Expedition. In Ergebnisse der Plankton-Expedition der Humboldt-Stiftung (Hensen, V. editor), vol. 4, I-88. Lipsius und Tischer, Kiel.

Williams, D.E., Burgoyne, D.L., Rettig, S.J., Andersen, R.J., Fathi-Afshar, Z.R. \& AlLen, T.M. (1993). The isolation of majusculamide C from the sponge Ptilocaulis trachys collected in Enewetak and determination of the absolute configuration of the 2-methyl-3-aminopentanoic acid residue. J. Nat. Prod., 56 : 545-551.

WiLliams, E.H. \& Bunkiey-W ILliams, L. (1990). The worldwide coral reef bleaching cycle and related sources of coral mortality. Atoll Res. Bull., 335 : $1-71$.

Yahel, G., Post, A.F., Fabricius, K., Marie, D., Vaulot, D. \& Genin, A. (1998). Phytoplankton distribution and grazing near coral reefs. Limnol. Oceanogr., 43 : 551-563.

Zaneveld, J.S. (1988). The Cyanophyta of the Ross Sea Islands and coastal Victoria Land Antarctica. Koeltz Scientific Books, Koenigstein.

ZhANG, Y. \& HofFMANN, L. (1982). Blue-green algal mats of the salinas in San-ya, Hai-nan Island (China): structure, taxonomic composition, and implications for the interpretation of Precambrian stromatolites. Precambrian Res., 56 : 275-290. 